\title{
Gonadal Pathology and Tumor Risk in Relation to Clinical Characteristics in Patients with 45,X/46,XY Mosaicism
}

\author{
M. Cools, J. Pleskacova, H. Stoop, P. Hoebeke, E. Van Laecke, S. L. S. Drop, \\ J. Lebl, J. W. Oosterhuis, L. H. J. Looijenga, ${ }^{*}$ and K. P. Wolffenbuttel, ${ }^{*}$ on \\ behalf of the Mosaicism Collaborative Group \\ Department of Pediatrics (M.C.), Division of Pediatric Endocrinology, and Department of Urology (P.H., \\ E.V.L.), University Hospital Ghent and Ghent University, 9000 Ghent, Belgium; Department of Pathology \\ (J.P., H.S., J.W.O., L.H.J.L.), Erasmus Medical Center, Josephine Nefkens Institute, Daniel Den Hoed \\ Cancer Center, and Departments of Pediatrics (S.L.S.D.) and Urology (K.P.W.), Division of Pediatric \\ Endocrinology, Erasmus Medical Center, Sophia Children's Hospital, 3000-DR Rotterdam, The \\ Netherlands; and Department of Pediatrics (J.P., J.L.), Charles University, Second Faculty of Medicine, \\ University Hospital Motol, 10034 Prague, Czech Republic
}

Context: Gonadectomy is avoided whenever possible in boys with $45, \mathrm{X} / 46, \mathrm{XY}$. However, no clinical markers are currently available to guide clinicians in predicting gonadal tumor risk or hormone production.

Objective: The objective of the study was to test the hypothesis that gonadal histology and risk for development of a malignant germ cell tumor are reflected by the clinical presentation of a $45, X / 46, X Y$ individual.

Design: The design of the study was the correlation of clinical data [external masculinization score (EMS), pubertal outcome] with pathology data (gonadal phenotype, tumor risk).

Setting: This was a multicenter study involving two multidisciplinary disorder of sex development teams.

Patients: Patients included genetically proven 45,X/46,XY (and variants) cases, of whom at least one gonadal biopsy or gonadectomy specimen was available, together with clinical details.

Interventions: Patients ( $n=48$ ) were divided into three groups, based on the EMS. Gonadal histology and tumor risk were assessed on paraffin-embedded samples $(n=87)$ by morphology and immunohistochemistry on the basis of established criteria.

Main Outcome Measures: Gonadal differentiation and tumor risk in the three clinical groups were measured. Clinical outcome in patients with at least one preserved gonad was also measured.

Results: Tumor risk in the three groups was significantly related to the gonadal differentiation pattern $(P<0.001)$. In boys, hormone production was sufficient and was not predicted by the EMS.

Conclusions: The EMS reflects gonadal differentiation and tumor risk in patients with 45, X/46,XY. In boys, testosterone production is often sufficient, but strict follow-up is warranted because of malignancy risk, which appears inversely related to EMS. In girls, tumor risk is limited but gonads are not functional, making gonadectomy the most reasonable option. (JClin Endocrinol Metab 96: E1171-E1180, 2011)

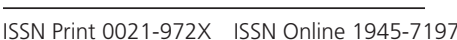

Printed in U.S.A.

Copyright $\odot 2011$ by The Endocrine Society

doi: 10.1210/jc.2011-0232 Received January 26, 2011. Accepted March 28, 2011

First Published Online April 20, 2011 * L.H.J.L. and K.P.W. contributed equally to this work.
Abbreviations: CIS, Carcinoma in situ; DSD, disorder of sex development; EMS, external
masculinization score; FISH, fluorescence in situ hybridization; HE, hematoxylin-eosin; SCF,
stem cell factor; TSPY, testis-specific protein on Y; UGT, undifferentiated gonadal tissue. 
$\mathbf{S}$ ex chromosome mosaicism $(45, \mathrm{X} / 46, \mathrm{XY}$ and variants) occurs with an estimated incidence of 1.5 per 10,000 (1) and may be due to loss of the Y chromosome through anaphase lag or to interchromosomal rearrangements with final loss of a structurally abnormal Y chromosome. The clinical spectrum is highly heterogeneous, with no obvious correlation between the phenotypic appearance and the respective cell line counts on routine peripheral blood karyotyping (1-3) or even on the basis of gonadal cell line counts (4). Up to $95 \%$ of individuals may live undiagnosed as normal males (1). However, ambiguous genitalia in a newborn but also mild undervirilization (e.g. hypospadias) in boys or even typical Turner syndrome in girls may be associated with 45, X/46, XY mosaicism (3).

Individuals with $45, \mathrm{X} / 46, \mathrm{XY}$, as some other patients with a disorder of sex development (DSD), more specifically those who have (a specific part of) the Y chromosome in their karyotype (eventually only at the gonadal level) are at increased risk for the development of malignant germ cell tumors $(5,6)$, referred to as type II germ cell tumors (7) (see Ref. 8 for a review). This has been related to the presence and aberrant expression of the testis-specific protein on Y (TSPY) gene, proximal on Yp (9-13).

The recent change in attitude toward clinical management of DSD patients, with increased emphasis on a conservative approach, and the delay of irreversible surgery until adulthood (14-17) has created doubt concerning the optimal approach with regard to gonads at risk for malignant transformation, e.g. in individuals with $45, \mathrm{X} /$ 46 , XY mosaicism and male gender. Gonadectomy is not the treatment of choice in these patients, but on the basis of a review of the relevant literature, tumor risk in $45, \mathrm{X} /$ $46, \mathrm{XY}$ individuals has been reported to be around $15 \%$ (8). However, clinical experience suggests a much lower incidence in 45,X/46,XY Turner syndrome girls. On the other hand, recent research has identified undifferentiated gonadal tissue (UGT), for which $45, \mathrm{X} / 46, \mathrm{XY}$ is a known risk factor, as the precursor lesion for gonadoblastoma $(18,19)$. More generally, on the basis of pathological studies in gonadal samples from DSD patients, it has been demonstrated that a disturbed process of gonadal development, affecting Sertoli or granulosa cell differentiation and function, results in insufficient microenvironmental stimuli for the germ cells and hence in a delay or block in their maturation. Immature germ cells are immunohistochemically characterized by increased TSPY expression and prolonged expression of embryonic germ cell markers, including the octamer binding transcription factor 3/4 (OCT3/4), encoded by the gene Pit-Oct-Unc domain class 5 transcription factor 1 (POU5F1) (18, 20-23), a condition that has been linked to malignant transformation and proliferation (13). The precise function of TSPY remains unknown. However, its aberrant expression has been related to increased proliferation of germ cells and oncogenic activity (10-12, 24-26). In embryonic stem cells, OCT3/4 is involved in the maintenance of pluripotency $(27,28)$, but in primordial germ cells, the experimental data rather suggest a role in their survival (29). In this context, the position of the OCT3/4 positive germ cells within the testis tubule is of relevance: a luminal position corresponds to simple maturation delay, whereas a position on the basal lamina points at resistance to apoptosis of a nonphysiological immature germ cell (20). Immunohistochemical staining for the c-KIT ligand stem cell factor (SCF; also known as KITLG), which is of pathogenetic relevance in the development of germ cell tumors $(30,31)$, constitutes an important additional marker supporting the differential diagnosis between maturation delay and neoplastic transformation of germ cells because SCF positivity is consistently detected in carcinoma in situ (CIS), gonadoblastoma, and testicular germ cell tumor but not in testes with maturation delay $(32,33)$. Thus, recent research has provided us with tools to detect not only the early pathogenetic stages of CIS and gonadoblastoma but also to identify premalignant lesions and germ cells at risk for neoplastic transformation, allowing to predict tumor development in gonadal biopsy samples and prophylactically removed gonads at a young age (8, 19, 33-35).

The present study was designed to refine our knowledge on tumor risk in the highly heterogeneous condition, which is 45,X/46,XY mosaicism. Specifically we examined whether a precise description of the clinical phenotype could be supportive in optimal patient management, including gonadal surgery and follow-up for tumor risk.

\section{Materials and Methods}

\section{Collection of gonadal samples and clinical data}

Most samples ( $\mathrm{n}=75$, from 39 patients), obtained by biopsy or gonadectomy, were retrieved from the archives of the pathology departments of the Erasmus Medical Center Rotterdam, the University Hospital Ghent, and the University Hospital Motol, Prague. Samples were reviewed by M.C., J.P., and J.W.O., experienced in gonadal histology and germ cell tumor pathology. The 45,X/46,XY mosaicism was diagnosed on the basis of routine karyotyping, in case of doubt, additional investigations based on local protocols [fluorescence in situ hybridization (FISH) with centromere Y probe, buccal smear chromosome analysis, gonadal karyotpying by FISH] were used to confirm the diagnosis. Patients were excluded if sufficient or reliable clinical data were not available or if the diagnosis 45,X/46XY (or variants) mosaicism was uncertain. Clinical data were recorded by the treating physicians (M.C., P.H., E.V.L., J.L., S.L.S.D., and K.P.W.) and reviewed by M.C. and J.P. Additional samples ( $\mathrm{n}=$ 12 , from nine patients) were obtained from referring centers; 
TABLE 1. Overview of the study population and available samples

Patients and samples

\begin{tabular}{lccc}
\hline & $\begin{array}{c}\text { Mild undervirilization } \\
(\text { EMS } \geq \mathbf{7})\end{array}$ & $\begin{array}{c}\text { Ambiguous phenotype } \\
\text { (EMS }<\text { 7) }\end{array}$ & $\begin{array}{c}\text { Female phenotype } \\
\text { (Turner syndrome) }\end{array}$ \\
\hline Patients & 10 & 14 & 23 \\
Gonadal samples & 15 & 24 & 46 \\
$\quad$ Biopsy & 9 & 6 & 46 \\
Gonadectomy & 6 & 18 & \\
Sex of rearing & 10 & 10 & 23 \\
Male & 0 & 4 & 12.2 \\
Female & 4.0 & 2.2 & \\
Mean age at surgery $(\mathrm{yr})$ & & & \\
\hline
\end{tabular}

EMS and sex of rearing unknown in one patient.

corresponding clinical data were provided by the treating pediatric endocrinologists. Patients were classified into three groups, based on the external masculinization score (EMS), which represents a clinical scoring system (based on the position of the gonads, length of the phallus, presence of scrotal fusion, and position of the urethral meatus) to quantitatively assess the degree of undervirilization in DSD patients (36). The EMS was calculated from data of the first clinical presentation: group 1, mild undervirilization, EMS 7-12; group 2, ambiguous phenotype, EMS less than 7; and group 3, female phenotype, representing in fact girls with Turner syndrome (without clitoromegaly).

\section{Immunohistochemical staining}

Tissue fixation was performed with $10 \%$ formalin for $24 \mathrm{~h}$, followed by paraffin embedding and preparation of slices of 3 $\mu \mathrm{m}$ thickness. For immunohistochemistry, heat-induced antigen retrieval was applied in all stainings. OCT3/4 (Santa Cruz Biotechnology, Santa Cruz, CA), dilution 1:350; for pretreatment $\mathrm{H}_{2} \mathrm{O}_{2}$ for $5^{\prime}+$ biotin blocking was used; the incubation time was $2 \mathrm{~h}$ at room temperature; the secondary antibody was biotinylated rabbit-antimouse. TSPY (kindly provided by Professor C. Lau, Department of Medicine, VA Medical Center, University of California, San Francisco, CA) was used at a dilution of 1:3000; incubation time was overnight at $4 \mathrm{C}$; the secondary antibody was swine-antirabbit, biotin labeled. SCF (Santa Cruz Biotechnology) was used at a dilution of 1:350 to 1:500, with an incubation time of overnight at $4 \mathrm{C}$; the secondary antibody was hoarse-antigoat, biotin labeled. Detection was performed using diaminobenzidine $/ \mathrm{H}_{2} \mathrm{O}_{2}$ (OCT3/4) or New Fuchsin/Naphtol ASMX phosphate (Sigma, Steinheim, Germany) (TSPY, SCF), and counterstaining was with hematoxylin.

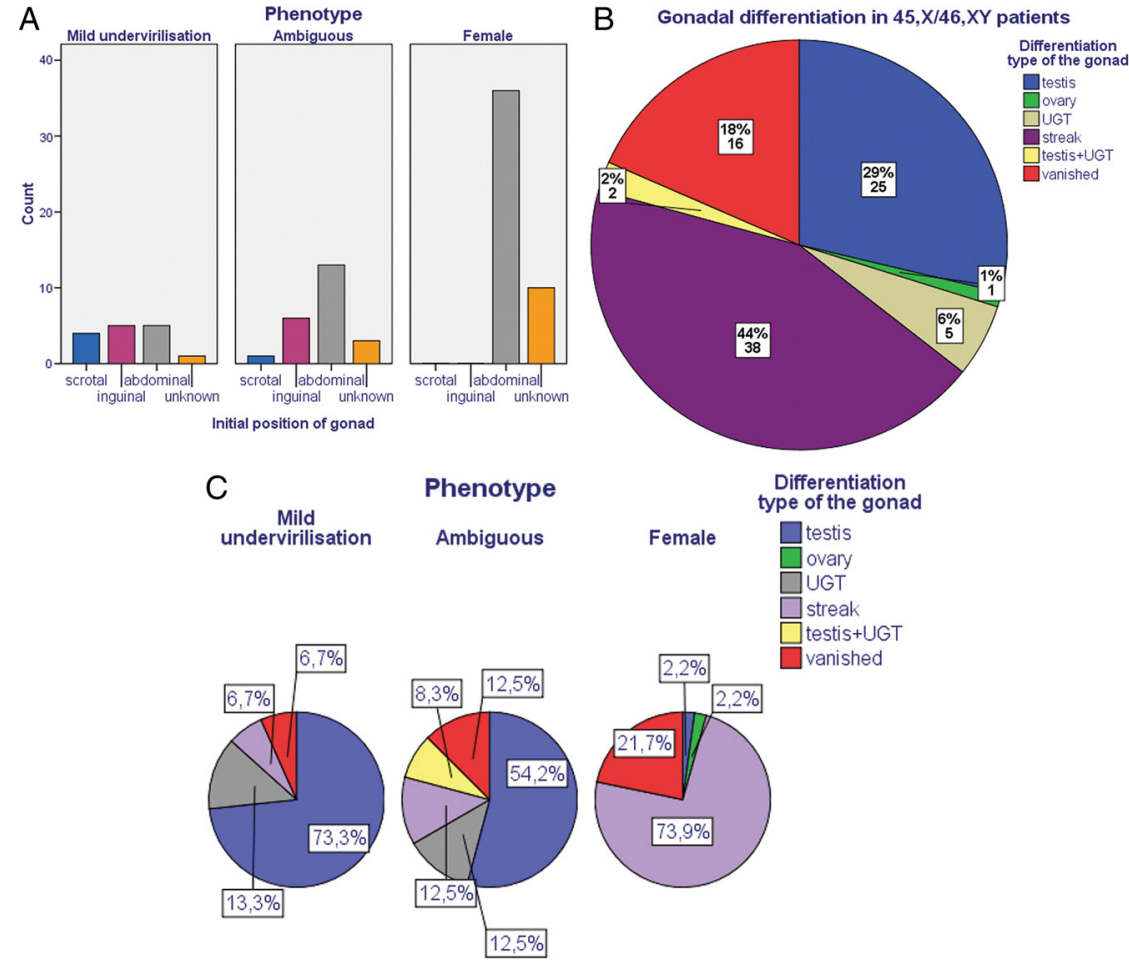

FIG. 1. A, Location of the gonads in the different phenotypic groups. Samples with an unknown position contained no gonadal tissue on microscopic evaluation. B, Distribution of the encountered gonadal differentiation patterns. C, Distribution of gonadal differentiation patterns in the different phenotypic groups.

\section{Microscopy and assessment of tumor risk}

Based on the general morphology, as assessed on hematoxylin-eosin (HE) staining, the samples were categorized as (dysgenetic) testis, UGT, ovary, streak, or a combination of these. The sample was considered to be at risk for germ cell tumor development if either an in situ neoplastic lesion (gonadoblastoma or CIS) or one or more indices for premalignancy (UGT, OCT3/4 positive cells on the basal lamina of testis tubules, or positive SCF staining) were present.

\section{Statistical analysis}

Results were analyzed with the SPSS software (version 15.0; Chicago, IL), comparison of categorical variables was performed using a Fisher exact test.

\section{Ethics}

The study was approved by the medical ethical committees of the University Hospital Ghent (MEC 2008/098), the Erasmus Medical Center Rotterdam (MEC 02.981), and University Hospital Motol Prague (EC 237/09). The samples were used according 

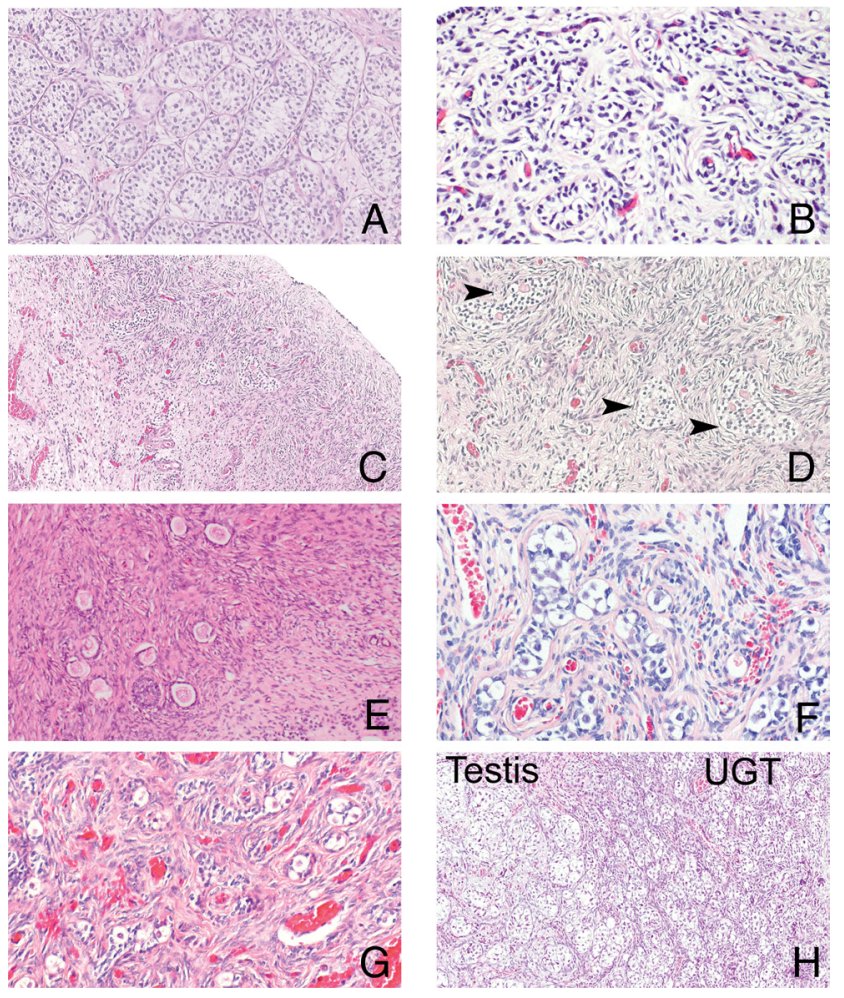

FIG. 2. Representative examples of the gonadal differentiation patterns that were encountered in our series of patients with $45, \mathrm{X} /$ 46,XY mosaicism. A, Normal testis, HE, $\times 200$. B, Dysgenetic testis tubules, showing a thin basal lamina, an irregular tubular shape, and increased stromal background, HE, $\times 200$. C, Streak, HE, $\times 100$. D, Enlargement of $C$, clearly showing primitive testis cord-like structures (arrows), HE, $\times 200 x . E$, Ovarian follicles, encountered in only one gonad in our series, HE, $\times 200$. F and G, UGT, HE, $\times 200$. H, Combined pattern with testis (left) and UGT (right), HE, $\times 100$

to the Code for Proper Secondary Use of Human Tissue in The Netherlands, as developed by the Dutch Federation of Medical Scientific Societies (version 2002).

\section{Results}

An overview of the patients and samples is provided in Table 1. The group of individuals with female phenotype is overrepresented, which probably relates to the finding that most $45, \mathrm{X} / 46, \mathrm{XY}$ cases live undiagnosed (as normal males) (1). Surgery is delayed in this group due to later diagnosis (mostly because of short stature) than in groups with mild undervirilization and ambiguous phenotype.

In 16 of 87 samples (18.3\%), no gonadal tissue was found; hence, for these samples (further referred to as vanished), the gonadal position could not be determined.

In total, 84 gonadal samples were considered for further analysis; one sample was excluded because it was a gonadectomy specimen of a previously biopsied gonad and revealed no new findings. In one patient who received a left biopsy and a right gonadectomy, the EMS could not be determined based on available clinical information. For the different phenotypic groups, the gonadal position, as recorded during the biopsy/gonadectomy procedures, is represented in Fig. 1A.

Figure $1 \mathrm{~B}$ shows the prevalence of the various gonadal differentiation patterns in our series, and Fig. 1C represents the distribution of these patterns within each phenotypic group.

Scrotal gonads were all recognized as testes. Gonads in the inguinal position were mostly testes ( $72 \%)$, although UGT $(18 \%)$ and streak $(9 \%)$ were also encountered. Abdominal gonads mostly presented as streak tissue $(68.5 \%)$, but interestingly, testis $(20.5 \%)$ or a combination of testis+UGT $(3.7 \%)$ is also possible. An abdominal gonad with UGT differentiation was found in $5.6 \%$, and the only gonad with ovarian differentiation was in the abdominal position (data not shown).

Figure 2 shows representative examples of the gonadal differentiation patterns that were encountered in the $45, \mathrm{X} /$ 46,XY individuals included in this study.

An in situ neoplasia, but no invasive tumor, was found in four different patients (Table 2). One patient with an EMS of 7.5 of 12 received prophylactic gonadectomy of a right abdominal gonad, which on microscopic examination contained UGT with gonadoblastoma. On the left side, a scrotal testis was present. One patient with an EMS of only one of 12 received prophylactic surgery at the age of $1 \mathrm{yr}$ and was found to have UGT with gonadoblastoma

TABLE 2. Summary of gonads containing tumors or preneoplastic lesions in patients with $45, X / 46, X Y$ mosaicism, taking into account the clinical phenotype

\begin{tabular}{lcccc}
\hline & $\begin{array}{c}\text { Mild } \\
\text { undervirilization }\end{array}$ & Ambiguous phenotype & Female phenotype & Total \\
\hline No risk & 14 & 21 & 45 & 80 \\
Tumor & 1 & 2 & 1 & 4 \\
Preneoplastic lesion & 1 & 10 & 0 & 11 \\
Risk $^{a}$ & $2 / 15(13 \%)$ & $12 / 23(52 \%)$ & $1 / 46(2.2 \%)$ & $15 / 84(18 \%)$ \\
\hline
\end{tabular}

All tumors in our series were in situ germ cell neoplastic lesions, discovered after prophylactic gonadectomy. There were no invasive tumors. Tumor risk was calculated from the presence of either an in situ neoplasia or preneoplastic changes, as described in Materials and Methods.

${ }^{a} P<0.001$. 


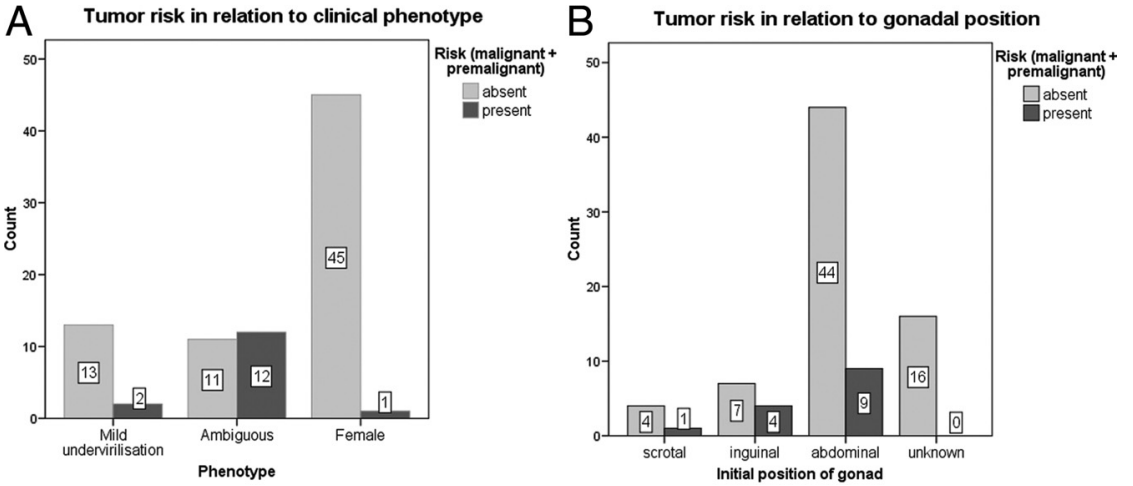

FIG. 3. A, The presence of premalignant lesions or an in situ neoplasia in the gonads from patients with 45,X/46,XY mosaicism, categorized according to their clinical phenotype. B, Presence of premalignant lesions or an in situ neoplasia in gonads from patients with $45, \mathrm{X} /$ $46, \mathrm{XY}$ mosaicism, categorized according to the position of the gonad.

in the left abdominal gonad; the right abdominal testis displayed no neoplastic features. One patient (EMS 1.5 of 12) had a gonadoblastoma in a severely dysgenetic inguinal testis; the right abdominal gonad was a streak. Surgery was performed at the age of $1 \mathrm{yr}$. The last patient was diagnosed with Turner syndrome after work-up for delayed puberty. None of the treating physicians noticed any clitoral enlargement. However, prophylactic gonadectomy, performed at the age of $16 \mathrm{yr}$, revealed a testis containing CIS in the right abdominal gonad, whereas the left specimen contained no gonadal tissue.

Fifteen gonads, including the four with an in situ neoplastic lesion, in 12 different patients, displayed premalignant characteristics. The prevalence of premalignant lesions was significantly different in the three groups $(P<$ $0.001)$ and is represented in Table 2 and Fig. $3 \mathrm{~A}$. The three patients with bilateral premalignant lesions had an ambiguous phenotype. Inguinal gonads displayed (pre)malignant characteristics more frequently compared with scrotal or abdominal gonads; however, the difference was not statistically significant $(P=0.09)$ (Fig. 3B).

Clinical and hormonal data of individuals with at least one preserved gonad or before gonadectomy were available in seven children, three pubertal boys, and one adult man. These data (summarized in Table 3 ) suggest a moderate to normal testosterone production in childhood and no clear correlation between the EMS at first presentation and testosterone levels. In the four (post) pubertal individuals, pubertal onset was spontaneous and progression through puberty normal. The adult man is infertile but testosterone levels are adequate without hormone supplementation.

\section{Discussion}

Tumor risk has been estimated at $15 \%$ in $45, \mathrm{X} / 46, \mathrm{XY}$ individuals (8). However, in clinical practice, histological examination of prophylactically removed gonads in Turner girls with $45, \mathrm{X} / 46, \mathrm{XY}$ suggests a much lower incidence, whereas no data are available for boys with 45,X/46,XY. Specifically in this group, it is of interest to preserve gonads to allow endogenous hormone production and therefore spontaneous puberty induction and maintenance. In previous years, tools have been developed by our group to recognize germ cells with premalignant characteristics, such as a maturation delay or block of germ cells, an immature environment, and an increased potential to proliferate and to resist apoptosis $(13,18,20-23,32)$ (reviewed in Refs. 7, 8, 19, 34, 35, and 37-39). It was shown that a combination of these characteristics may lead to CIS or gonadoblastoma, depending on the context of the microenvironment $(18,20,40,41)$. For CIS, it has been demonstrated that all cases will become invasive over a lifetime period (42); for gonadoblastoma this is less clear. This study was undertaken to examine in a large series of patients with $45, \mathrm{X} / 46, \mathrm{XY}$, clinically a very heterogeneous group, if the clinical phenotype reflects the gonadal phenotype and tumor risk, and whether this may provide a tool in clinical practice to guide management with regard to gonadal biopsy or gonadectomy in this patient population.

The distribution of the respective cell lines as obtained from peripheral blood karyotyping was not taken into account for this study because previous observations revealed no correlation between peripheral blood karyotype and gonadal karyotype or gonadal differentiation patterns (4).

Morphological examination of the specimen revealed some interesting findings. First, the absence of gonadal tissue was observed frequently in our series $(18 \%)$, as in other causes of gonadal dysgenesis (M. Cools, unpublished observation). Although theoretically it cannot be excluded that the surgeon missed the gonad while performing the gonadectomy procedure, this is unlikely, taking into account the frequency of this finding and the experience of the involved surgeons. Therefore, we hypothesize a mechanism in which the gonadal anlage, if unable to develop into a more mature stage, regresses by apoptosis. Second, categorization of gonadal differentiation patterns in $45, \mathrm{X} / 46, \mathrm{XY}$ was difficult because they represent a continuum between two extremes (normal testis and normal ovary) rather than easily determinable separate entities, as is shown in Fig. 2. Third, streak, defined as nonfunctional gonadal tissue, or even UGT was often 
TABLE 3. Summary of available clinical functional data in male patients with at least one preserved gonad or in females before gonadectomy

\begin{tabular}{|c|c|c|c|c|c|}
\hline Patient & EMS & Gonadal position $^{a}$ & Assessment & $\mathbf{T}$ & Remarks \\
\hline \multicolumn{6}{|l|}{ Childhood } \\
\hline 3 & 8.5 & 1 inguinal testis & $\mathrm{HCG}, 3 \mathrm{yr}$ & $60 \mathrm{ng} / \mathrm{dl}(2.1 \mathrm{nmol} / \mathrm{liter})^{b}$ & \\
\hline & & 1 scrotal testis & HCG, $10 \mathrm{yr}$ & $54 \mathrm{ng} / \mathrm{dl}\left(1.9 \mathrm{nmol} / \mathrm{liter}^{b}\right)^{b}$ & \\
\hline 8 & 7.5 & & & & gonadectomy \\
\hline 14 & 1 & $\begin{array}{l}1 \text { abdominal testis } \\
1 \text { abdominal UGT }\end{array}$ & $\mathrm{HCG}$ & Good & \\
\hline 28 & 4.5 & $\begin{array}{l}1 \text { abdominal testis } \\
1 \text { inguinal testis }\end{array}$ & $\mathrm{HCG}, 2$ wk & $140 \mathrm{ng} / \mathrm{dl}(4.8 \mathrm{nmol} / \mathrm{liter})^{\mathrm{c}}$ & \\
\hline 35 & 4 & 1 abdominal testis & T, 3 wk & $135 \mathrm{ng} / \mathrm{dl}(4.7 \mathrm{nmol} / \text { liter })^{\mathrm{c}}$ & $\begin{array}{l}\text { Bilateral gonadectomy } \\
\text { and raised female }\end{array}$ \\
\hline 37 & 5.5 & $\begin{array}{l}1 \text { vanished gonad } \\
1 \text { inguinal testis } \\
1 \text { scrotal testis }\end{array}$ & T, 2 wk & $172 \mathrm{ng} / \mathrm{dl}(6.0 \mathrm{nmol} / \mathrm{liter})^{\mathrm{c}}$ & \\
\hline 38 & 4.5 & 1 abdominal testis & HCG, 9 months & $459 \mathrm{ng} / \mathrm{dl}(15.9 \mathrm{nmol} / \mathrm{liter})^{c}$ & $\begin{array}{l}\text { Bilateral gonadectomy } \\
\text { and raised female }\end{array}$ \\
\hline \multicolumn{6}{|l|}{ (Post)puberty } \\
\hline 2 & 11.5 & $\begin{array}{l}1 \text { inguinal testis } \\
1 \text { scrotal testis }\end{array}$ & $\mathrm{PE}$ & $\mathrm{P} 3 \mathrm{G} 3,6 / 6 \mathrm{ml}$ & No T suppletion \\
\hline 5 & 8 & $\begin{array}{l}1 \text { scrotal testis (originally } \\
\text { inguinal) }\end{array}$ & $\begin{array}{l}\mathrm{PE}, \mathrm{FSH}, \mathrm{US} \text {, sperm } \\
\text { count }\end{array}$ & $\begin{array}{c}\text { NI pubertal development, } \\
\text { FSH } \uparrow \text {, infertility, NI US }\end{array}$ & $\begin{array}{l}\text { Actually } 30 \text { yr old, no } \\
\text { T suppletion }\end{array}$ \\
\hline 10 & 4.5 & $\begin{array}{l}1 \text { scrotal testis } \\
\text { (originally inguinal) }\end{array}$ & $\mathrm{PE}$ & $\mathrm{G} 2,4 \mathrm{ml}$ & No T suppletion \\
\hline 12 & 1.5 & 1 scrotal testis & $\mathrm{PE}, \mathrm{FSH}$ & & $\begin{array}{l}\text { Actually } 15 \text { yr old, no } \\
\text { T suppletion }\end{array}$ \\
\hline
\end{tabular}

Assay and age-specific baseline references (reference values after HCG were not available): T, Serum testosterone obtained after the functional assessment; HCG, human chorion gonadotrophin test; PE, physical examination; US, Ultrasound; NI, normal.

${ }^{a}$ At the moment of assessment.

${ }^{b} 8.6-14.4 \mathrm{ng} / \mathrm{dl}(0.3-0.5 \mathrm{nmol} / \mathrm{liter})$.

c $14-363 \mathrm{ng} / \mathrm{dl}(0.5-12.6 \mathrm{nmol} / \mathrm{liter})$.

referred to as ovarian-type stroma in official pathology reports, probably due to the background of stromal cells. However, the terminology of ovarian-type stroma was interpret by some clinicians as ovarian tissue (defined by the presence of follicles including germ cells), eventually available for cryopreservation. In fact, irrespective of the clinical phenotype, the finding of ovarian follicles was rare in 45,X/46,XY mosaicism (one of 87 samples), even from tissue removed at a very young age. This is in contrast to observations in 45, X and 45, X/46, XX gonads (43). Likewise, ovarian follicles in the context of an ovotestes (defined as the copresence of testis and ovarian tissue, including follicles, in one individual) were not encountered in our population, unlike in $46, \mathrm{XX} / 46, \mathrm{XY}$ chimerism (M. Cools, unpublished observation). Streak tissue (in our series present in $44 \%$ of samples) by definition does not contain germ cells, but also in dysgenetic testes and UGT, germ cells were scarce. Increased apoptosis of germ cells has been attributed to a defective microenvironment and impaired meiosis of aneuploid germ cells (44).
Tumor risk was significantly reflected by the clinical phenotype in our series $(P<0.001)$ and revealed to be very high $(52 \%)$ in cases with an ambiguous phenotype. This group had the highest prevalence of UGT $(20.8 \%)$, which has been recognized as the precursor lesion for gonadoblastoma (18) (Fig. 1C). Moreover, testes, if present, were severely dysgenetic in this group and often contained immature OCT3/4-positive cells on the basal lamina, in contrast to patients with mild undervirilization, in whom UGT was less frequently observed (13.3\%), and testes had attained a more mature stage, with less pronounced shape irregularity of the tubules and more frequent loss of OCT3/4 expression in germ cells that had reached the basal lamina. Moreover, testes were more often in the scrotal position in this group (Fig. 1A). Cryptorchidism is known as an independent risk factor for the development of germ cell tumors (45), which has been related to maturation delay of germ cells (46). This risk is probably higher in inguinal than in abdominal gonads due to early apoptosis of germ cells in the latter position (Ref. 47 and 
Clinical presentation $45, \mathrm{X} / 46, \mathrm{XY} D S D$

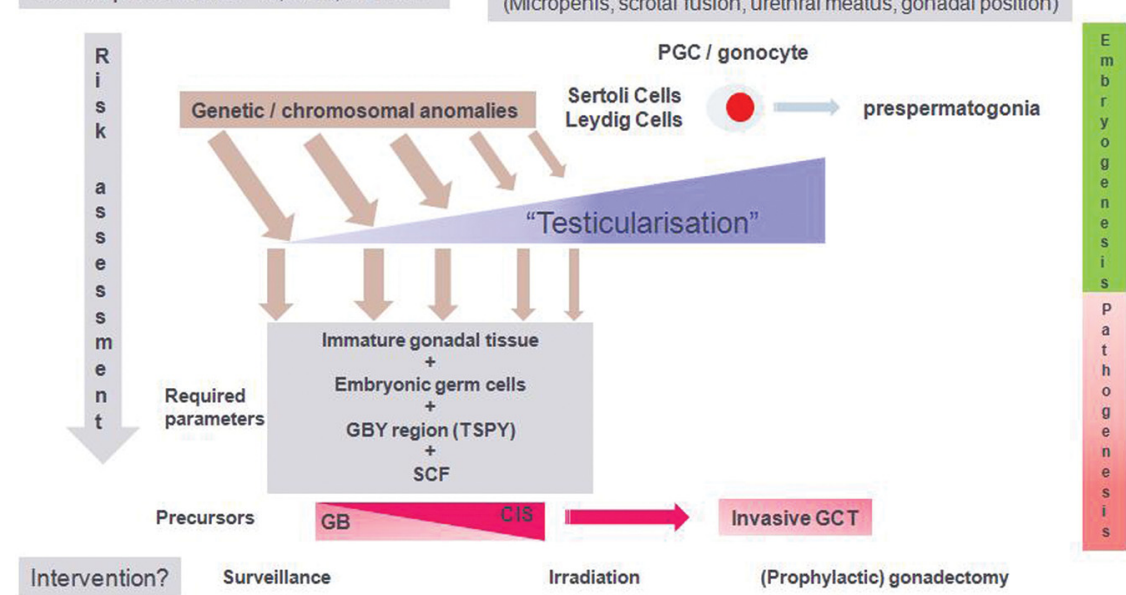

FIG. 4. Suggested pathophysiology of germ cell tumor development in $45, X / 46, X Y$ gonads. The EMS score quantitatively describes the patient's phenotype. Higher EMS scores correlate with a more advanced process of testis formation at the gonadal level. Disturbed gonadal development, resulting from the abnormal karyotype, leads to impaired Sertoli/granulosa cell function. Subsequently germ cells escape the normal control mechanisms exerted by the supportive cell lineage (i.e. differentiation and mitotic or meiotic arrest), causing a delay or block in their normal maturation process and leading to increased survival (prolonged OCT3/ 4) and proliferation (increased TSPY) chances. Especially in gonads with a low degree of testicularization, the four parameters required for malignant proliferation of germ cells are present, leading to a high risk for the development of gonadoblastoma or CIS, depending on the microenvironment and subsequently to an invasive germ cell tumor. PGC, Primordial germ cell; GB, gonadoblastoma; GBY, gonadoblastoma region on Y; GCT, germ cell tumor. [Adapted with permission from L. H. Looijenga et al.: Best Pract Res Clin Endocrinol Metab 24:291-310, 2010 (19). (c) Elsevier.]

M. Cools, unpublished observation). In our study, inguinal gonads revealed the highest tumor risk, but this was not statistically significant, maybe due to small sample size (Fig. 3B). Twenty percent of 45, X/46,XY testes with spontaneous scrotal descent revealed premalignant characteristics, but this number represents in fact only one of five gonads, from an individual with an EMS of 5.5 and so belonging to the ambiguous phenotype group. In interpreting these data, it has to be kept in mind that the differentiation patterns in these gonads and the clinical phenotypes of the patients were very heterogeneous, independently influencing tumor risk, in contrast to studies in patients with simple cryptorchidism. In the phenotypically female group, most gonads were streak or had vanished, resulting in a low tumor risk (Table 1 and Fig. 1C). Only one of 46 gonads (2.2\%), from a 16-yr-old girl with Turner syndrome and a vanished gonad on the contra-lateral side, displayed testis differentiation, notably with CIS. Remarkably, no virilization, not even clitoral enlargement, was noticed in this girl. The reason for the discrepancy between this gonad and the 45 other samples from this group remains unexplained.

The phenotype in all our patients revealed some degree of undervirilization. Thus, due to selection bias (obviously, no gonadal specimen were available from individuals who live undiagnosed), we are unable to predict tumor risk in normal males with a 45,X/46,XY constitution, representing in fact the largest clinical group (1). However, from our findings as described above, it can be hypothesized that in these individuals, the risk is low because the clinical picture of a normal EMS score and bilaterally descended testes suggests a (close to) normal testicular differentiation and maturation process. Moreover, the absence of reports in the literature on testicular germ cell tumors in males in whom a $45, \mathrm{X} /$ 46 , XY karyotype was unexpectedly found is in line with this hypothesis.

Functional outcome data in males with at least one preserved gonad were scarce but suggest a sufficiently conserved Leydig cell function to allow spontaneous puberty, with, as expected, high FSH levels, predicting impaired Sertoli cell function, and infertility (48). However, these preliminary data emphasize the benefit for the male $45, \mathrm{X} / 46, \mathrm{XY}$ individual if gonadectomy can be avoided. Guidelines for conservative follow-up of these patients, and for the timing and handling of testicular biopsies, are waiting.

In 45,X/46,XY Turner girls, without signs of virilization, tumor risk is low, but the gonadal tissue, if present, in most cases is a nonfunctional streak, making the preservation of these gonads of no use. However, in cases in which the girl is very reluctant to have surgery, or if surgery is contraindicated, gonadectomy can be postponed without great risk.

The question remains whether, in cases of phenotypical Turner syndrome and a diagnosis of 45 , X monosomy after routine cytogenetic analysis, additional investigations are warranted to detect hidden mosaicism. FISH analysis with centromere $\mathrm{X}$ and $\mathrm{Y}$ probes on interphase nuclei, which is reported to be superior to PCR in this context due to a lower number of false-positive results, reveals an additional 46,XX cell line in 30\% and a 46,XY cell line in 10\% of cases (49). In view of this high number and in contrast to previous suggestions (8), we currently subscribe to the American College of Medical Genetics guidelines, suggesting routine screening for hidden mosaicism in all 45,X women by additional FISH analysis on 200 interphase 
TABLE 4. Guidelines for individualized management with regard to gonadectomy in $45, X / 46, X Y$ mosaicism

\begin{tabular}{l} 
Management guidelines \\
\hline Mild undervirilization (EMS $\geq 7$ ) \\
Orchidopexy \\
Regular self-examination (every 3 months) and ultrasound \\
(annually) from puberty onward \\
One prepubertal biopsy (ideally between ages 1 and 9 yr or \\
in combination with an orchidopexy procedure) and one \\
post pubertal biopsy (e.g. at $17-25$ yr of age) to assess \\
tumor risk by specialized immunohistochemistry \\
In case of premalignant changes (OCT3/4 positive cells on \\
the basal lamina/expression of SCF/presence of UGT) or in \\
situ neoplasia: gonadectomy (or irradiation?) \\
Ambiguous genitalia (EMS < 7 ) \\
See guidelines for mild undervirilization \\
Low threshold to perform gonadectomy (e.g. insufficient \\
hormone production necessitating hormone replacement \\
therapy; impossibility to bring the gonad in a stable scrotal \\
position; suspicion for malignancy on physical examination \\
or ultrasound; immunohistochemical abnormalities related \\
to pre-CIS lesions, such as OCT3/4 positive cells on the \\
basal lamina or positive stem cell factor staining; or \\
presence of UGT on the biopsy) \\
Female phenotype \\
Elective gonadectomy (if patient is reluctant to \\
gonadectomy, consider leaving the gonads in place) \\
Cryopreservation not indicated
\end{tabular}

The approach to the $45, X / 46, X Y$ patient can be individually tailored, based on his/her phenotype, and varies from careful surveillance, (repeated) biopsy, irradiation of a CIS lesion, or prophylactic gonadectomy (see also Fig. 4).

nuclei harvested from buccal smear (49). However, to resolve this long-standing question, we believe it is mandatory to report on tumor incidence in larger series of $45, \mathrm{X} /$ 46 , XY Turner women in whom even discrete signs of virilization, pointing at the presence of some testicular differentiation at the gonadal level, were explicitly sought and excluded.

To summarize, our data suggest that the tumor risk in $45, \mathrm{X} / 46, \mathrm{XY}$ patients is most pronounced in immature and/or poorly differentiated gonadal tissue and that the degree of testicularization of the gonad (defined as the process of testicular development in its broadest sense) is reflected by the clinical phenotype (19). This hypothesis can modify our clinical approach to the $45, \mathrm{X} / 46, \mathrm{XY}$ patient, resulting in an individualized management with regard to tumor risk and gonadectomy (Fig. 4 and Table 4). Future research and long-term follow-up of these patients is necessary to demonstrate the safety and benefit of this approach.

\section{Acknowledgments}

We thank explicitly all referring clinicians (J. P. Bourguignon, M. Maes, G. Massa, G. Holmdahl, R. Gannaway, R. Goerse,
O. Hiort, C. Clementson, J. Horejsi, M. Snajderova, J. Zapletalova, and D. Novotna) as well as the Pathology Departments of the University Hospital Ghent and the University Hospital Prague-Motol for their support in collecting tissue and clinical data. Members of the Mosaicism Collaborative Group include the following: J. P. Bourguignon, Department of Pediatrics, Sart Tilman University Hospital, Liège, Belgium; Kockum C. Clementson, Department of Pediatric Surgery, University Hospital Lund, Sweden; R. Gannaway, Department of Human and Molecular Genetics, Virginia Commonwealth University Medical Center, Richmond, VA; D. Gisselsson, Department of Clinical Genetics, University Hospital Lund, Sweden; R. Goerse, Department of Gynecology, University Hospital Regensburg, Germany; O. Hiort, Department of Pediatrics, University Hospital Schleswig-Holstein, Campus Lübeck, Germany; G. Holmdahl, Department of Pediatric Surgery, Queen Silvia Children's Hospital, Gothenburg, Sweden; M. Maes, Department of Pediatrics, University Hospital Saint-Luc, Brussels, Belgium; and G. Massa, Department of Pediatrics, Virga Jesse Hospital, Hasselt, Belgium.

Address all correspondence and requests for reprints to: Martine Cools, Department of Pediatrics, University Hospital Ghent, De Pintelaan 185, 9000 Ghent, Belgium. E-mail: martine.cools@ugent.be.

This work was supported by research grants from the Flanders Research Foundation (to M.C.) and the European Society of Pediatric Endocrinology, sponsored by Novo Nordisk A/S (to J.P.).

Disclosure Summary: The authors have nothing to disclose.

\section{References}

1. Chang HJ, Clark RD, Bachman H 1990 The phenotype of 45,X/ 46,XY mosaicism: an analysis of 92 prenatally diagnosed cases. Am J Hum Genet 46:156-167

2. Grumbach MM, Hughes IA, Conte FA 2003 Disorders of sex differentiation. In: Larsen PR, Kronenberg HM, Melmed S, Polonsky KM, eds. Williams textbook of endocrinology. 10th ed. Philadelphia: W.B. Saunders (Elsevier); 842-1002

3. Telvi L, Lebbar A, Del Pino O, Barbet JP, Chaussain JL 1999 45,X/ 46,XY mosaicism: report of 27 cases. Pediatrics 104(2 Pt 1):304308

4. Cools M, Boter M, van Gurp R, Stoop H, Poddighe P, Lau YF, Drop SL, Wolffenbuttel KP, Looijenga LH 2007 Impact of the Y-containing cell line on histological differentiation patterns in dysgenetic gonads. Clin Endocrinol (Oxf) 67:184-192

5. Verp MS, Simpson JL 1987 Abnormal sexual differentiation and neoplasia. Cancer Genet Cytogenet 25:191-218

6. Scully RE 1970 Gonadoblastoma. A review of 74 cases. Cancer 25:1340-1356

7. Oosterhuis JW, Looijenga LH 2005 Testicular germ-cell tumours in a broader perspective. Nat Rev Cancer 5:210-222

8. Cools M, Drop SL, Wolffenbuttel KP, Oosterhuis JW, Looijenga LH 2006 Germ cell tumors in the intersex gonad: old paths, new directions, moving frontiers. Endocr Rev 27:468-484

9. Page DC 1987 Hypothesis: a Y-chromosomal gene causes gonadoblastoma in dysgenetic gonads. Development 101(Suppl):151-155 
10. Lau YF 1999 Gonadoblastoma, testicular and prostate cancers, and the TSPY gene. Am J Hum Genet 64:921-927

11. Lau Y, Chou P, Iezzoni J, Alonzo J, Kömüves L 2000 Expression of a candidate gene for the gonadoblastoma locus in gonadoblastoma and testicular seminoma. Cytogenet Cell Genet 91:160-164

12. Li Y, Tabatabai ZL, Lee TL, Hatakeyama S, Ohyama C, Chan WY, Looijenga LH, Lau YF 2007 The Y-encoded TSPY protein: a significant marker potentially plays a role in the pathogenesis of testicular germ cell tumors. Hum Pathol 38:1470-1481

13. Kersemaekers AM, Honecker F, Stoop H, Cools M, Molier M, Wolffenbuttel K, Bokemeyer C, Li Y, Lau YF, Oosterhuis JW, Looijenga LH 2005 Identification of germ cells at risk for neoplastic transformation in gonadoblastoma. Hum Pathol 36:512-521

14. Hughes IA, Houk C, Ahmed SF, Lee PA 2006 Consensus statement on the management of intersex disorders. Arch Dis Child 91:554563

15. Hughes IA 2010 The quiet revolution: disorders of sex development. Best Pract Res Clin Endocrinol Metab 24:159-162

16. Wiesemann C, Ude-Koeller S, Sinnecker GH, Thyen U 2010 Ethical principles and recommendations for the medical management of differences of sex development (DSD)/intersex in children and adolescents. Eur J Pediatr 169:671-679

17. Creighton SM, Minto CL, Liao LM, Alderson J, Simmonds M 2004 Meeting between experts: evaluation of the first U.K. forum for lay and professional experts in intersex. Patient Educ Couns 54:153157

18. Cools M, Stoop H, Kersemaekers AM, Drop SL, Wolffenbuttel KP, Bourguignon JP, Slowikowska-Hilczer J, Kula K, Faradz SM, Oosterhuis JW, Looijenga LH 2006 Gonadoblastoma arising in undifferentiated gonadal tissue within dysgenetic gonads. J Clin Endocrinol Metab 91:2404-2413

19. Looijenga LH, Hersmus R, de Leeuw BH, Stoop H, Cools M, Oosterhuis JW, Drop SL, Wolffenbuttel KP 2010 Gonadal tumours and DSD. Best Pract Res Clin Endocrinol Metab 24:291-310

20. Cools M, van Aerde K, Kersemaekers AM, Boter M, Drop SL, Wolffenbuttel KP, Steyerberg EW, Oosterhuis JW, Looijenga LH 2005 Morphological and immunohistochemical differences between gonadal maturation delay and early germ cell neoplasia in patients with undervirilisation syndromes. J Clin Endocrinol Metab 90:5295-5303

21. Cools M, Honecker F, Stoop H, Veltman JD, de Krijger RR, Steyerberg E, Wolffenbuttel KP, Bokemeyer C, Lau YF, Drop SL, Looijenga LH 2006 Maturation delay of germ cells in trisomy 21 fetuses results in increased risk for the development of testicular germ cell tumors. Hum Pathol 37:101-111

22. Honecker F, Stoop H, de Krijger RR, Chris Lau YF, Bokemeyer C, Looijenga LH 2004 Pathobiological implications of the expression of markers of testicular carcinoma in situ by fetal germ cells. J Pathol 203:849-857

23. Stoop H, Honecker F, Cools M, de Krijger R, Bokemeyer C, Looijenga LH 2005 Differentiation and development of human female germ cells during prenatal gonadogenesis: an immunohistochemical study. Hum Reprod 20:1466-1476

24. Oram SW, Liu XX, Lee TL, Chan WY, Lau YF 2006 TSPY potentiates cell proliferation and tumorigenesis by promoting cell cycle progression in HeLa and NIH3T3 cells. BMC Cancer 6:154

25. Li Y, Vilain E, Conte F, Rajpert-De Meyts E, Lau YF 2007 Testisspecific protein $\mathrm{Y}$-encoded gene is expressed in early and late stages of gonadoblastoma and testicular carcinoma in situ. Urol Oncol 25:141-146

26. Lau YF, Lau HW, Kömuves LG 2003 Expression pattern of a gonadoblastoma candidate gene suggests a role of the $\mathrm{Y}$ chromosome in prostate cancer. Cytogenet Genome Res 101:250-260

27. Niwa H, Miyazaki J, Smith AG 2000 Quantitative expression of Oct-3/4 defines differentiation, dedifferentiation or self-renewal of ES cells. Nat Genet 24:372-376
28. Matin MM, Walsh JR, Gokhale PJ, Draper JS, Bahrami AR, Morton I, Moore HD, Andrews PW 2004 Specific knockdown of Oct4 and $\beta 2$-microglobulin expression by RNA interference in human embryonic stem cells and embryonic carcinoma cells. Stem Cells 22: $659-668$

29. Kehler J, Tolkunova E, Koschorz B, Pesce M, Gentile L, Boiani M, Lomelí H, Nagy A, McLaughlin KJ, Schöler HR, Tomilin A 2004 Oct4 is required for primordial germ cell survival. EMBO Rep 5:1078-1083

30. Rapley EA, Turnbull C, Al Olama AA, Dermitzakis ET, Linger R, Huddart RA, Renwick A, Hughes D, Hines S, Seal S, Morrison J, Nsengimana J, Deloukas P, Rahman N, Bishop DT, Easton DF, Stratton MR 2009 A genome-wide association study of testicular germ cell tumor. Nat Genet 41:807-810

31. Kanetsky PA, Mitra N, Vardhanabhuti S, Li M, Vaughn DJ, Letrero R, Ciosek SL, Doody DR, Smith LM, Weaver J, Albano A, Chen C, Starr JR, Rader DJ, Godwin AK, Reilly MP, Hakonarson H, Schwartz SM, Nathanson KL 2009 Common variation in KITLG and at $5 \mathrm{q} 31.3$ predisposes to testicular germ cell cancer. Nat Genet 41:811-815

32. Stoop H, Honecker F, van de Geijn GJ, Gillis AJ, Cools MC, de Boer M, Bokemeyer C, Wolffenbuttel KP, Drop SL, de Krijger RR, Dennis N, Summersgill B, McIntyre A, Shipley J, Oosterhuis JW, Looijenga LH 2008 Stem cell factor as a novel diagnostic marker for early malignant germ cells. J Pathol 216:43-54

33. van de Geijn GJ, Hersmus R, Looijenga LH 2009 Recent developments in testicular germ cell tumor research. Birth Defects Res C Embryo Today 87:96-113

34. Hersmus R, de Leeuw BH, Wolffenbuttel KP, Drop SL, Oosterhuis JW, Cools M, Looijenga LH 2008 New insights into type II germ cell tumor pathogenesis based on studies of patients with various forms of disorders of sex development (DSD). Mol Cell Endocrinol 291: $1-10$

35. Looijenga LH, Hersmus R, Oosterhuis JW, Cools M, Drop SL, Wolffenbuttel KP 2007 Tumor risk in disorders of sex development (DSD). Best Pract Res Clin Endocrinol Metab 21:480-495

36. Ahmed SF, Khwaja O, Hughes IA 2000 The role of a clinical score in the assessment of ambiguous genitalia. BJU Int 85:120-124

37. Honecker F, Oosterhuis JW, Mayer F, Hartmann JT, Bokemeyer C, Looijenga LH 2004 New insights into the pathology and molecular biology of human germ cell tumors. World J Urol 22:15-24

38. de Jong J, Stoop H, Dohle GR, Bangma CH, Kliffen M, van Esser JW, van den Bent M, Kros JM, Oosterhuis JW, Looijenga LH 2005 Diagnostic value of OCT3/4 for pre-invasive and invasive testicular germ cell tumours. J Pathol 206:242-249

39. Cools M, Looijenga LH, Wolffenbuttel KP, Drop SL 2009 Disorders of sex development: update on the genetic background, terminology and risk for the development of germ cell tumors. World J Pediatr 5:93-102

40. Hersmus R, de Leeuw BH, Stoop H, Bernard P, van Doorn HC, Brüggenwirth HT, Drop SL, Oosterhuis JW, Harley VR, Looijenga LH 2009 A novel SRY missense mutation affecting nuclear import in a $46, \mathrm{XY}$ female patient with bilateral gonadoblastoma. Eur J Hum Genet 17:1642-1649

41. Hersmus R, Kalfa N, de Leeuw B, Stoop H, Oosterhuis JW, de Krijger R, Wolffenbuttel KP, Drop SL, Veitia RA, Fellous M, Jaubert F, Looijenga LH 2008 FOXL2 and SOX9 as parameters of female and male gonadal differentiation in patients with various forms of disorders of sex development (DSD). J Pathol 215:31-38

42. Giwercman A, Müller J, Skakkebaek NE 1991 Prevalence of carcinoma in situ and other histopathological abnormalities in testes from 399 men who died suddenly and unexpectedly. J Urol 145: $77-80$ 
43. Borgström B, Birgit B, Hreinsson J, Julius H, Rasmussen C, Carsten R, Sheikhi M, Maryam S, Fried G, Gabriel F, Keros V, Victoria K, Fridström M, Margareta F, Hovatta O, Outi H 2009 Fertility preservation in girls with turner syndrome: prognostic signs of the presence of ovarian follicles. J Clin Endocrinol Metab 94:74-80

44. Kocer A, Reichmann J, Best D, Adams IR 2009 Germ cell sex determination in mammals. Mol Hum Reprod 15:205-213

45. Giwercman A, Grindsted J, Hansen B, Jensen OM, Skakkebaek NE 1987 Testicular cancer risk in boys with maldescended testis: a cohort study. J Urol 138:1214-1216

46. Rajpert-De Meyts E, Jorgensen N, Brondum-Nielsen K, Muller J, Skakkebaek NE 1998 Developmental arrest of germ cells in the pathogenesis of germ cell neoplasia. APMIS 106:198-204; discussion 204-206

47. Abouzeid AA, Mousa MH, Soliman HA, Hamza AF, Hay SA 2011 Intra-abdominal testis: histological alterations and significance of biopsy. J Urol 185:269-274

48. Chada M, Prùsa R, Bronský J, Kotaska K, Sídlová K, Pechová M, Lisá L 2003 Inhibin B, follicle stimulating hormone, luteinizing hormone and testosterone during childhood and puberty in males: changes in serum concentrations in relation to age and stage of puberty. Physiol Res 52:45-51

49. Wolff DJ, Van Dyke DL, Powell CM 2010 Laboratory guideline for Turner syndrome. Genet Med 12:52-55

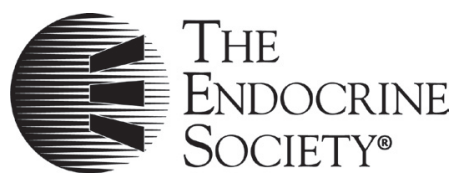

\section{Refer a new active member and you could receive a $\$ 10$ Starbucks Card when they join.}

